\title{
Using silage inoculants to improve the quality of pasture and maize silage in New Zealand
}

\author{
J. J. KLEINMANS, W. R. DEWAR, H. J. H. ERASMUS, R. J. DENSLEY \\ Genetic Technologies Ltd., P.O. Box 105 303, Auckland
}

jkleinmans@genetic.co.nz

\begin{abstract}
Silage is an important supplement in New Zealand dairy systems, however quality can be variable. Challenges with pasture silage lie mainly in the fermentation process, while maize silages tend to have a better fermentation profile, but are prone to heating and spoilage at feed-out. A series of laboratory scale silo trials were used to investigate the effect of different silage inoculants on aerobic stability in maize silage $(n=8)$ and fermentation quality in pasture silage $(n=6)$. Inoculants affected aerobic stability in maize silage, and $\mathrm{pH}$, fermentation losses, ammonia- $\mathrm{N}$ and fermentation acid profile in pasture silage, however products differed in their efficacy. Farmers can make better inoculant purchase decisions by choosing products that have supporting trial data as well as guaranteed bacteria numbers.
\end{abstract}

\section{Introduction}

Pasture and/or maize silage is fed by more than $90 \%$ of New Zealand dairy farmers (Versus Research Ltd pers. comm.). Silage quality is affected by two main factors: the quality of the material ensiled and the fermentation process. Efficient silage fermentation decreases losses of dry matter (DM) and energy during the ensiling and feed-out process. This will result in higher milk response.

During fermentation, epiphytic lactic acid bacteria (LAB) ferment the water-soluble carbohydrates (WSC) in the crop to lactic acid, and to a lesser extent acetic acid. Due to the production of these acids, the $\mathrm{pH}$ of the ensiled material decreases and spoilage microorganisms are inhibited (Oude Elferink et al. 1999).

The use of silage inoculants at harvest-time is common in many countries. These products contain strains of beneficial bacteria which are added to the crop in sufficient numbers to out-compete the epiphytic bacteria. There are a range of different bacteria used in inoculant products and they deliver different benefits (Muck 2010). Inoculants containing homofermentative lactic acid bacteria that produce only lactic acid are generally used to improve fermentation quality in crops such as pasture which can have a low fermentation coefficient due to a lower sugar level and higher buffering capacity (Oude Elferink et al. 1999). Inoculants containing Lactobacillus buchneri, a heterofermentative species, improve aerobic stability of crops such as maize for silage which are prone to heating at feed-out time. Combination products that contain strains of homo-fermentative lactic-acid producing bacteria and hetero-fermentative Lactobacillus buchneri should deliver fermentation quality and aerobic stability benefits.

Silage inoculants have been proven to reduce fermentation losses and improve silage quality (Muck 2010). However, it has been recognised that there are differences in efficacy between commercially available products.

Inoculant quality testing schemes were introduced in the United Kingdom (AIC Forage Additive Register 2011) and Germany (DLG Gütezeichen für Siliermittel, 2011) to publicly list proven additives. Approvals for demonstrated effects are given for different categories: fermentation quality, aerobic stability, effluent run-off and animal performance.

The objectives of this research were to test a range of commercially available silage inoculant products to assess their ability to improve a) pasture silage fermentation quality and b) maize silage aerobic stability, and to provide practical recommendations for farmers on how to select inoculant products that are effective.

\section{Methods}

\section{Maize silage}

Eight trials were conducted during the 2010 maize silage harvest season to cover a range of different maize crops with different epiphytic bacteria populations. Maize plants were chopped using a garden shredder to a chop length of $10-15 \mathrm{~mm}$. Dry matter at ensiling averaged $33.5 \%$. Inoculant products were purchased from the marketplace during autumn 2010 silage harvest time.

The treatments were Control (no inoculant applied), Product A (Biosil Maize, Enterococcus faecium, Pediococcus acidilactici, Lactobacillus plantarum, Lactococcus lactis, Lactobacillus buchneri), Product B (Si-Lac Extra, Lactobacillus plantarum, Enterococcus faecium, Lactobacillus buchneri) and Product C (Pioneer $^{\circledR}$ brand 11C33, Lactobacillus plantarum, 
Table 1 Maize silage analysis after 60 days of ensiling (average of eight trials).

\begin{tabular}{lccccccc}
\hline Treatment & DM \% & $\mathrm{pH}$ & $\begin{array}{c}\text { Aerobic } \\
\text { Stability }(\mathrm{h})\end{array}$ & $\begin{array}{c}\text { Aerobic } \\
\text { Loss }(\%)\end{array}$ & $\begin{array}{c}\text { Lactic Acid } \\
(\% \mathrm{DM})\end{array}$ & $\begin{array}{c}\text { Acetic Acid } \\
(\% \mathrm{DM})\end{array}$ & $\begin{array}{c}\text { Propandiol } \\
(\% \mathrm{DM})\end{array}$ \\
\hline Untreated & $33.8^{\mathrm{a}}$ & 3.76 & $39.3^{\mathrm{a}}$ & $6.76^{\mathrm{a}}$ & 5.30 & $1.27^{\mathrm{a}}$ & $0^{\mathrm{a}}$ \\
$\mathrm{A}$ & $33.3^{\mathrm{b}}$ & 3.76 & $38.7^{\mathrm{a}}$ & $6.61^{\mathrm{a}}$ & 5.35 & $1.29^{\mathrm{a}}$ & $0^{\mathrm{a}}$ \\
$\mathrm{B}$ & $32.6^{\mathrm{c}}$ & 3.76 & $38.3^{\mathrm{a}}$ & $7.39^{\mathrm{a}}$ & 5.41 & $1.31^{\mathrm{a}}$ & $0^{\mathrm{a}}$ \\
$\mathrm{C}$ & $32.2^{\mathrm{c}}$ & 3.76 & $94.8^{\mathrm{b}}$ & $4.52^{\mathrm{b}}$ & 5.65 & $1.62^{\mathrm{b}}$ & $0.29^{\mathrm{b}}$ \\
SEM & 1.03 & 0.007 & 10.4 & 1.17 & 0.029 & 0.014 & 0.006 \\
\hline
\end{tabular}

${ }^{a, b}$ values with different superscripts within columns are significantly different $(P<0.01)$

Table $2 \mathrm{pH}$ development in pasture silage ensiled in vacuum pack silos (average of six trials).

\begin{tabular}{|c|c|c|c|c|c|c|c|}
\hline \multirow[t]{2}{*}{ day } & \multicolumn{6}{|c|}{ Treatment } & \multirow[t]{2}{*}{ SEM } \\
\hline & Untreated & D & $E$ & $\mathrm{~F}$ & $\mathrm{G}$ & $\mathrm{H}$ & \\
\hline 1 & $6.40^{\mathrm{b}}$ & $6.35^{\mathrm{ab}}$ & $6.28^{\mathrm{ab}}$ & $6.37^{\mathrm{ab}}$ & $6.38^{\mathrm{ab}}$ & $6.25^{a}$ & 0.08 \\
\hline 3 & $5.88^{b}$ & $5.79^{b}$ & $5.70^{\mathrm{ab}}$ & $5.67^{\mathrm{ab}}$ & $5.71^{\mathrm{ab}}$ & $5.57^{a}$ & 0.20 \\
\hline 7 & $4.86^{\mathrm{b}}$ & $4.88^{b}$ & $4.86^{b}$ & $4.92^{\mathrm{b}}$ & $4.86^{\mathrm{b}}$ & $4.70^{\mathrm{a}}$ & 0.19 \\
\hline 15 & $4.53^{b}$ & $4.59^{\mathrm{bc}}$ & $4.60^{\mathrm{bc}}$ & $4.60^{b c}$ & $4.69^{\circ}$ & $4.32^{\mathrm{a}}$ & 0.17 \\
\hline 60 & $4.08^{b}$ & $4.12^{\mathrm{b}}$ & $4.09^{b}$ & $4.09^{b}$ & $4.06^{\mathrm{b}}$ & $3.94^{a}$ & 0.09 \\
\hline
\end{tabular}

${ }^{a, b}$ values with different superscripts within rows are significantly different $(P<0.01)$

Enterococcus faecium, Lactobacillus buchneri at 1.10 $\times 10^{11}$ colony forming units (cfu)/g product).

Forage was weighed out for each treatment set of silos in a trial, and spread out on a $(2 \mathrm{~m} \times 2 \mathrm{~m})$ sheet of plastic. Inoculants were evenly applied to the forage according to manufacturer's recommendation and mixed manually by rolling the forage on the plastic. At all times precautions were taken to prevent cross contamination between treatments. Forage was weighed $(500 \mathrm{~g})$, vacuum packed into bags using a Sunbeam Foodsaver ${ }^{\circledR}$ vacuum sealer, and heat sealed. This method allows consistent ensiling conditions across treatments and trials (Johnson et al. 2005) and allows comparison with larger scale silos (Wilson \& Wilkins 1972). Three vacuum pack silos were assigned to each treatment within each study.

Samples of forage were taken prior to vacuum packing and after ensiling (day 60) and frozen for analysis. Vacuum packs were opened at day 29 of fermentation for 24 hours and again vacuum sealed according to the guidelines of the German silage additive testing scheme for the approval of improved silage aerobic stability (DLG 2000). At day 60, packs were opened and evaluated for aerobic stability. This is defined as the length of time (hours) before the silage temperature increased $1.7^{\circ} \mathrm{C}$ above the ambient temperature after exposure to air according to the method described by Honig (1986).
A quantity of silage equivalent to $100 \mathrm{~g} \mathrm{DM}$ was placed in a 1 litre plastic container insulated with styrofoam in a temperature controlled $\left(20^{\circ} \mathrm{C}\right)$ room. Temperature in the centre of the silage mass was measured every three hours for 1 week using an in-situ temperature probe. This is a standardised method of estimating how long a silage face can be exposed to air before it starts to heat and losses occur.

Maize pre-ensiling samples were oven dried at $62{ }^{\circ} \mathrm{C}$ overnight (residual moisture typically $5 \%$ ) and ground to pass a $1.0 \mathrm{~mm}$ screen. Nutritional quality was determined by near infrared spectroscopy at Hill Laboratories (Hamilton, New Zealand). Metabolisable energy (ME) was calculated from dry organic matter digestibility using Agricultural and Food Research Council and Lincoln University standard formulae.

Day 60 samples oven dried at $105^{\circ} \mathrm{C}$ for 48 hours and analysed for fermentation acids by HPLC (Siegfried et al.1984; Canale et al. 1984) and $\mathrm{pH}$ by Pioneer HiBred International (Buxtehude, Germany). Data were analysed using a linear mixed model of the SAS system (SAS version 9.2 software, SAS Institute Inc., Cary NC, USA) with treatment being considered a fixed effect and location a random effect. The effect of treatment at a location served as the error to test treatment effects.

\section{Pasture silage}

Six pasture silage trials were conducted during spring 2010. Precision chopped pasture was collected from 
Table $3 \quad \mathrm{CO}_{2}$ losses from pasture silage ensiled in 2.7 litre laboratory silos (average of six trials).

\begin{tabular}{|c|c|c|c|c|c|c|c|}
\hline \multirow[t]{2}{*}{ day } & \multicolumn{6}{|c|}{ Treatment } & \multirow[t]{2}{*}{ SEM } \\
\hline & Untreated & D & E & $\mathrm{F}$ & G & $\mathrm{H}$ & \\
\hline 1 & 0.037 & 0.039 & 0.036 & 0.039 & 0.040 & 0.035 & 0.009 \\
\hline 3 & 0.184 & 0.185 & 0.176 & 0.184 & 0.182 & 0.172 & 0.043 \\
\hline 7 & 0.401 & 0.393 & 0.381 & 0.386 & 0.389 & 0.358 & 0.06 \\
\hline 14 & $0.554^{\mathrm{b}}$ & $0.554^{b}$ & $0.531^{\mathrm{ab}}$ & $0.536^{a b}$ & $0.539^{\mathrm{ab}}$ & $0.469^{a}$ & 0.06 \\
\hline 28 & $0.757^{b}$ & $0.756^{b}$ & $0.717^{\mathrm{b}}$ & $0.763^{b}$ & $0.738^{\mathrm{b}}$ & $0.603^{a}$ & 0.10 \\
\hline 64 & $0.995^{\mathrm{ab}}$ & $1.008^{b}$ & $0.936^{\mathrm{ab}}$ & $1.155^{\mathrm{b}}$ & $1.045^{\mathrm{b}}$ & $0.804^{\mathrm{a}}$ & 0.14 \\
\hline
\end{tabular}

a,b values with different superscripts within rows are significantly different $(P<0.01)$

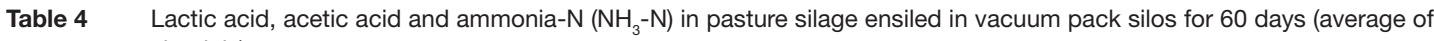
six trials).

\begin{tabular}{|c|c|c|c|c|c|c|c|}
\hline \multirow[t]{2}{*}{ Item } & \multicolumn{6}{|c|}{ Treatment } & \multirow[t]{2}{*}{ SEM } \\
\hline & Untreated & D & $E$ & $\mathrm{~F}$ & $\mathrm{G}$ & $\mathrm{H}$ & \\
\hline Lactic acid & $6.44^{a}$ & $6.27^{a}$ & $6.48^{\mathrm{a}}$ & $5.97^{a}$ & $6.61^{a}$ & $7.97^{b}$ & 0.67 \\
\hline Acetic acid & $1.64^{\mathrm{b}}$ & $1.66^{\mathrm{b}}$ & $1.85^{\mathrm{b}}$ & $1.60^{\mathrm{b}}$ & $1.74^{b}$ & $1.02^{\mathrm{a}}$ & 0.27 \\
\hline Lactic/Acetic acid & $4.92^{a}$ & $4.49^{a}$ & $4.41^{\mathrm{a}}$ & $4.59^{\mathrm{a}}$ & $4.68^{\mathrm{a}}$ & $7.97^{b}$ & 1.15 \\
\hline $\mathrm{NH}_{3}-\mathrm{N}$ & $0.132^{\mathrm{c}}$ & $0.122^{\mathrm{bc}}$ & $0.117^{b}$ & $0.121^{\mathrm{bc}}$ & $0.118^{b}$ & $0.098^{a}$ & 0.018 \\
\hline
\end{tabular}

${ }^{a, b}$ values with different superscripts within rows are significantly different $(P<0.01)$

six different Waikato farms during pasture silage harvest to cover a range of different pastures with different epiphytic bacteria populations. Dry matter at ensiling averaged $39.2 \%$. A total of 12 small $(20 \mathrm{~g})$ vacuum pack silos, three large $(500 \mathrm{~g})$ vacuum pack silos and three PVC silos (plastic drainage pipe 10 $\mathrm{cm}$ diameter $\times 35 \mathrm{~cm}$ length with rubber caps on both ends; 2.7 litres) were assigned to each treatment within a study. Inoculant products were purchased from commercial sources during spring 2010 silage harvest time. The treatments were Control (no inoculant applied), Product D (Biosil, Enterococcus faecium, Pediococcus acidilactici, Lactobacillus plantarum, Lactococcus lactis), Product E (Si-Lac, Lactobacillus plantarum, Enterococcus faecium) Product F (SilAll 4x4, Lactobacillus plantarum, Enterococcus faecium, Pediococcus acidilactici, Lactobacillus salivarius, enzymes), Product G ( Silage King, blend of fermentation extracts) and Product $\mathrm{H}$ (Pioneer ${ }^{\circledR}$ brand 1174, Enterococcus faecium, Lactobacillus plantarum at $\left.1.25 \times 10^{11} \mathrm{cfu} / \mathrm{g}\right)$.

Forage was treated according to the method above. Vacuum pack silos were sealed and PVC silos were closed airtight. Samples of forage were taken prior to vacuum packing. The $20 \mathrm{~g}$ vacuum packs were frozen at $1,3,7$ and 15 days of fermentation and subsequently thawed for $\mathrm{pH}$ measurement. The $500 \mathrm{~g}$ vacuum packs were frozen at day 60 of fermentation and subsequently thawed for analysis of silage quality. PVC silos were weighed on a precision scale $(\mathrm{d}= \pm 0.1 \mathrm{~g})$ on days 0,1 , $3,7,14,28$ and 64 to determine $\mathrm{CO}_{2}$ losses.

Pasture pre-ensiling samples were analysed for nutritional quality and ME was determined by Hill Laboratories using the methods described above.

Day 60 samples were oven dried at $105^{\circ} \mathrm{C}$ for 24 hours and analysed for $\mathrm{pH}$, ammonia nitrogen (water extraction followed by Berthelot colorimetry) and fermentation acid profile (water extraction, IC analysis).

\section{Results}

\section{Maize silage}

Maize composition at ensiling averaged 33.5\% DM (29.4 - 38.7\%), 25.9\% DM starch (21.1 -30.2\%), 36.7\% DM neutral detergent fibre (NDF) (32.6 - 39.8\%) and 11.1 Megajoules (MJ) ME/kg DM (10.6 - 11.6 MJ ME/ $\mathrm{kg} \mathrm{DM})$. All silages fermented well, reaching a low $\mathrm{pH}$ of 3.8 and a fermentation acid profile typical for wellpreserved maize silage (Table 1). Untreated control maize silage heated within an average of 39.3 hours after silage was exposed to air. The aerobic stability and fermentation acid profiles for Products A and B did not differ from the control. Product $\mathrm{C}$ improved $(\mathrm{P}<0.01)$ aerobic stability by more than 2 days ( +55.5 hours). Analysis of fermentation acids in silages treated with Product $\mathrm{C}$ indicated higher acetic acid and propandiol concentrations (Table 1).

\section{Pasture silage}

Pasture composition at ensiling averaged 39.2\% DM 
(31.1 - 47.5\%), 15.1\% DM soluble sugars (13.0 - 16.8), $9.3 \%$ ash $(7.9-10), 11.6 \%$ crude protein $(8.4-16.1)$, 44.7\% NDF (42.6 - 47.8), 10.9 MJ ME/kg DM (10.3 - 11.6).

Results from six trials (Table 2 ) indicate a greater rate of $\mathrm{pH}$ decline $(\mathrm{P}<0.01)$ from day 1 to 60 with Product $\mathrm{H}$ compared with untreated silage. Other inoculants did not affect $\mathrm{pH}$ during fermentation when compared with untreated silage. When compared to the untreated control, losses of $\mathrm{CO}_{2}$ (Table 3$)$ were reduced $(\mathrm{P}<0.01)$ with Product $\mathrm{H}$ on days 14 and 28, but there was no difference in $\mathrm{CO}_{2}$ loss by day 60. Loss of $\mathrm{CO}_{2}$ from silage treated with other inoculants was not different from the untreated control. Silage quality after 60 days of fermentation (Table 4) indicate increased $(\mathrm{P}<0.01)$ lactic acid, a reduced acetic acid concentration and improved lactic to acetic acid ratio in silage treated with Product $\mathrm{H}$. Other inoculants did not differ from the control. Ammonia nitrogen $\left(\mathrm{NH}_{3}-\mathrm{N}\right)$, which indicates proteolysis which leads to lower feed value for the silage was lowest $(\mathrm{P}<0.01)$ in silage treated with Product H. Products E and $\mathrm{G}$ also reduced $(\mathrm{P}<0.01)$ ammonia-N levels compared with untreated silage, but levels were still greater than silage treated with Product $\mathrm{H}$.

\section{Discussion}

Maize silage generally has a high concentration of starch and sugar which makes it prone to aerobic instability. Yeasts can develop when stacks are opened and air penetrates with heating and subsequent moulding leading to DM and feed quality losses (Kung 2010). Concentration of fermentation acids in the Product C-treated silages reflect greater acetic acid and some propandiol compared with the untreated control, and an improvement in aerobic stability (+ 55.5 hours). There were no differences in the fermentation acid profile or the aerobic stability of silage treated with products $A$ and $\mathrm{B}$ when compared with the untreated control.

All the pasture samples were well fermented due to an ideal harvest DM content and relatively high soluble sugar concentrations. Generally, lactic acid is the preferred end product of fermentation because it is stronger than acetic acid, expediting the preservation of the forage. It was expected that inoculants containing homo-fermentative species (those which convert sugars to lactic acid only) would lower $\mathrm{pH}$ more quickly and more effectively than naturally occurring epiphytic bacteria, which are a mix of homo-fermentative and hetero-fermentative strains. Low $\mathrm{pH}$ inhibits the growth of many detrimental microorganisms and helps reduce proteolysis and other plant enzyme activity. Homo-fermentative fermentation also produces no $\mathrm{CO}_{2}$, thereby improving DM recovery from the silo compared with untreated silage (Muck 2010). In our trials, Product H-treated silage had greater lactic acid concentrations, lower acetic acid concentrations and an improved lactic acid to acetic acid ratio at day 60 . Losses of $\mathrm{CO}_{2}$ (Table 3) were also reduced in silage treated with Product $\mathrm{H}$ on days 14 and 28, but not on day 60 . These factors all indicate a more efficient initial fermentation by homo-fermentative lactic acid bacteria, but that DM losses by 60 days post-sealing were similar. For the $\mathrm{pH}$ and $\mathrm{CO}_{2}$ time course data, the authors did not include interactions with time or location in the statistical model. This could be investigated in further studies.

While this study shows that inoculants can effectively improve silage quality, it is important to recognise that some products had no positive impact on maize silage aerobic stability or pasture silage fermentation quality. This mirrors international research that has concluded that, while generally the results of using an inoculant are positive, some products perform better than others (Muck 2010).

To deliver fermentation or aerobic stability benefits, inoculants must supply the right combination of live bacteria in sufficient numbers to outcompete epiphytic bacteria and dominate the fermentation. Different inoculant strains have different effects on silage quality (Contreras-Govea \& Muck 2006) and aerobic stability (Muck 2004). Production methods and storage conditions can affect the number of active bacteria in the product when it is applied to forage. Product physical form and method of application can influence product distribution and influence whether the applied bacteria are more competitive than the epiphytic microflora. Muck (2010) recommends selecting inoculants that apply at least $100,000 \mathrm{cfu}$ per $\mathrm{g}$ crop. This requires a definable minimum number of live bacteria in the product at the time of use. Guaranteed bacterial counts on the product label is a first indication of product quality, however in this study bacterial counts were available only for Products $\mathrm{C}$ and $\mathrm{H}$. Product $\mathrm{G}$ contained a blend of fermentation extracts without any reference to bacteria species or numbers. Products B, C, $\mathrm{E}$ and $\mathrm{H}$ were liquid products; all others were granular products, typical of those being used by farmers. Whiter \& Kung (2001) demonstrated that liquid inoculants are more effective over a wider range of crop DM levels than granular products. While maize silage DM were in an acceptable range for granular products $(<40 \% \mathrm{DM}$; Muck 2010), three pasture silages were $40 \%$ DM or greater, which may partly explain the lack of positive results.

It is difficult for farmers to evaluate inoculant effectiveness on-farm. Good purchase decisions must be based on the results of published trials which have been conducted according to scientific protocols. 
Published trial data indicate that Product $\mathrm{H}$ increases beef live weight gain by $4.4 \mathrm{~kg} /$ tonne of forage ensiled (Soderlund 1989). Purchasing this product will cost the farmer around \$2.62/tonne forage treated and will, at a beef schedule price of $\$ 1.88 / \mathrm{kg}$ live weight, deliver a return of $\$ 2.62$ for each dollar spent on inoculant. Other inoculant products will have a comparable cost but farmers should ask for published trial data to determine likely returns. The results of this study show that some inoculants may not deliver advantages when compared with an untreated control.

\section{REFERENCES}

AIC (Agricultural Industries Confederation) Forage Additive Register 2011. Accessed 4/8/2011.http:// www.agindustries.org.uk/content.output/807/807/ AIC $\% 20$ Additional $\% 20$ Services $/ \mathrm{AIC} \% 20$ Additional $\% 20$ Services $/$ AIC $\% 20$ Forage $\% 20$ Additives\%20Register.mspx.

Canale, A.; Valente, M. E.; Ciotti, A.1984. Determination of volatile carboxylic acids (C1-C5i) and lactic acid in aqueous acid extracts of silage by high performance liquid chromatography. Journal of the Science of Food and Agriculture 35:1178 - 1182.

Contreras-Govea, F.; Muck, R. 2006. Microbial inoculants for silage. Focus on Forage. Accessed 4/8/2011 http://www.uwex.edu/ces/crops/uwforage/ Microbial Inoculants-FOF.htm.

DLG-Gütezeichen für Siliermittel 2011 (DLG quality label for silage additives) Accessed 4/8/2011. http:// www.dlg.org/siliermittel.html.

DLG 2000. Guidelines for the testing of silage additives for compliance with DLG quality label requirements. Available from: U.Rubenschuh@DLG.org .

Honig, H. 1986. Evaluation of aerobic stability. pp. 76-82. In: Proceedings of the Eurobac Conference, 12 - 16 August 1986, Uppsala, Sweden. Grovfoder Grass and Forage Reports, Swedish University of Agricultural Sciences, 3, 1990, Special Issue, ISSN 0280-6118, ISBN, 91-576-4525-6.

Johnson, H.E; Merry, R.J.; Davies, D.R.; Kell, D.B.; Theodorou, D.B.; Griffith, G.W. 2005. Vacuum packing: a model system for laboratory-scale silage fermentations. Journal of Applied Microbiology 98: 106-113.

Kung, L. 2010. Aerobic stability of silages. In: Proceedings of the California Alfalfa \& Forage Symposium and Corn/Cereal Silage Conference. Visalia, CA, 1-2 December, 2010. Accessed 4/8/2011. http://alfalfa.ucdavis.edu/+symposium/2010/files/talks/ CAS10 KungAnaerobicStability.pdf

Muck, R.E. 2004. Effects of corn silage inoculants on aerobic stability. Transactions of the ASAE 47 (4): 1011-1016. Accessed 4/8/2011. http://www. dfrc.ars.usda.gov/DFRCWebPDFs/2004-MuckTASAE-47-1011.pdf

Muck, R. E. 2010. Silage additives and management issues. In: Proceedings of the Idaho Alfalfa and Forage Conference 16-17 February 2010. Accessed 4/8/2011. http://www.extension.uidaho.edu/forage/ Proceedings $/ 2010 \% 20$ Proceedings/Silage $\% 20$ Additives $\% 20$ and $\% 20 \mathrm{Mgmt} \% 20$ Issues.pdf

Oude Elferink, S.J.W.H .; Driehuis, F.; Gottschal, J.C.; Spoelstra S.F.1999. Silage fermentation processes and their manipulation. In: Proceedings of the FAO Electronic Conference on Tropical Silage 1 September to 15 December 1999. Accessed 4/8/2011. http://www.fao.org/docrep/005/x8486e/x8486e09. htm\#bm9

Soderlund, S. 1989. Pioneer brand 1174 silage inoculant: the new generation of silage inoculants. Food for Thought, Pioneer Hi-Bred International. Second Forage Symposium Proceedings, p.215.

Siegfried, R.; Rückemann, H.; Stumpf, G. 1984. Eine HPLC-Methode zur Bestimmung organischer Säuren in Silagen (A HPLC method to determine organic acids in silages). Landwirtschaftliche Forschung, Sonderdruck 37 (3-4): 298-304.

Whiter, A.G., Kung, L. 2001. The effect of a dry or liquid application of Lactobacillus plantarum MTD1 on the fermentation of alfalfa silage. Journal of Dairy Science 84: 2195-2202.

Wilson R.F., Wilkins, R.J. 1972. An evaluation of laboratory ensiling techniques. Journal of the Science of Food and Agriculture 23: 377-385. 
